\title{
A Boy Who Loved Knives: Resilience Supported through Successful Psychotherapy
}

\section{Peter A Olsson*}

Stowecroft Drive; Hampton, NH, USA

*Corresponding author: Peter Alan Olsson, 21 Stowecroft Drive; Hampton, NH 03842, USA, Tel: 603-313-9946; Email: polsson2@comcast.net

\section{Case Report}

Volume 2 Issue 2

Received Date: July 02, 2018

Published Date: July 19, 2018

DOI: $10.23880 /$ mhrij-16000123

\section{Abstract}

Unlike many melodramatic Hollywood movie scenarios, changes occurring in psychotherapy are often deceptively quiet, often muted. Psychotherapy involves many emotional experiences-anxiety, fear, fascination, wonder, boredom, humor/laughter, anger, sadness, and often pain. The more severe and ominous forms of pain, destruction, and even a death prevented, go unheralded. They are unnoticed because existentially they like a suicide prevented, never, in fact, exist or occur. This paper presents detailed child psychotherapy work with a highly anxious conflicted twelve-year-old boy. Robbie's case is presented in the form of a short story to protect his privacy and to demonstrate exquisite detail of the psychotherapy process. Psychotherapy helped ten-year-old Robbie and his family deal effectively with painful family secrets. Robbie resolved his fears and conflicts and got back on track in his life to become a normal contented person.

\section{Case Report}

The long, endless seeming ...SCREECH! Sharpening is accompanied by showers of shiny metal sparks like fireworks flying off the Carborundum grinding wheel at Jack and Jake's Sharpening shop. Now, a welcome soothing silence arrives, like a cold drink on a scorching hot summer day.

Robbie Wilson sat in his bedroom staring at his math book. The numbers danced and jumped around on the page of his math book. The subtraction stuff is always harder for him than the adding. Robbie liked things to be added, not taken away. Robbie wished he was with Dad and Uncle Jake out in their backyard shop right now. Not here, trying to do math homework.

Robbie Wilson says to himself,
"That screech noise used to bug me. I told dad it hurt my ears."

Dad laughed and said,

"Robbie my boy, if there were no screeching, our family would starve and have no clothes to wear."

Then, after saying stuff like that, Dad laughed. I love my dad's laugh...it has a music in it. He and Uncle Jake work all day together in their shop behind our house. The big sign on the shop says, JACK \& JAKE-WE--R-- SHARPERS. They laugh and joke and have fun at work. I don't think too many parents or grown-ups have fun at work. Dad and uncle Jake use ear plugs most of the time during the screeches. But, no screeches allowed after supper. That's when Dad and Jake do paperwork ...stuff like, printing bills to send; opening mail; licking stamps; recording checks that will be put in 


\section{Mental Health \& Human Resilience International Journal}

the bank soon. Dad and Uncle Jake don't even know it but when I was younger I used to sneak out at night and watch them work and listen to them talk through the screen windows. I hope that I can work with Dad and Uncle Jake someday. The sign on the shop then will say, JACK, JAKE \& ROB--WE--R--SHARPERS.

My mom is more serious than dad. Mom's name is Martha. Mom worries a lot. She worries about my school grades. I don't like school. But, Dad says I have to get at least through high school so I can work with him and Jake. They say I have to be able to add up all our money. Then they laugh. They love to laugh. I want to laugh a lot someday too.

Mom works for the Houston Sewer department. "Solid and liquid waste management department" is the real name. Dad and Jake call it the poop and pee department. Dad kid's mom that she doesn't smell like she works in the sewer. Mom smiles a little when Dad says stuff like that... I think mom secretly likes dad's jokes ... I think they stink but, I laugh too.

I don't know why I stink at school... besides my not liking it. I try to study in my room in the evening, but I keep thinking about Dad and Jake at their office out back. I wish I could be grownup already. I wish there was a special time machine that could make me twenty one right now, rather than only eleven. Mom tries to help me study, but she isn't very good at math teaching.

Dad would be better at teaching me, but he is busy working. Besides, he teaches me all kinds of good stuff about knives, swords, bayonets, lawnmowers, scythes, sickles, hatchets, axes, saws, chainsaws, tree trimmers, strop razors, hedge trimmers, machetes, sabers, daggers, throwing knives, fencing foils, rapiers, scalpels, switch-blades, fighting knives, pocket knives, Swiss Army knives, Boy Scout knives, carving knives, kitchen knives, and Exacta knives. My favorite knife is a United States Marine KBAR knife. My grandpa Johnnie was a marine. He left the KBAR to me when he died. Marine's use their K Bar in combat, to hack through jungles, to help dig foxholes, and even open cans of beans. Dad and Jake say good knife sharpening takes special skill, care and love. They say it's an art...then they laugh their musical laughs.

See you later; I really got to try to study now...."

Robbie Wilson and his mother sat waiting at the Houston Child Psychiatry Clinic for their appointment with doctor Lord. Robbie hated being there. His mother hoped for help.
In efforts to train resident physicians in psychiatry and to promote objective observation and reliable medical record-keeping, university hospitals and clinics require careful and meticulously organized record forms. Some observers could say that medical forms are a domain where hard science does devilish dances with scientism. Others cynically say records are for protection against lawsuits. If the clinician doesn't write it down, the court treats it as if the good thing they did doesn't even exist. This allows mistakes to stand out in relief. One of Lord's medical school teachers said about records---they allow science and technology to protect helpers master primitive fear superstition and doubt.

Jim Lord like most doctors, hated paperwork .But, he gritted his teeth and sat down to write.

\section{Evaluation Form: Houston Child Psychiatry Clinic}

\section{Dentifying Information}

Name: Robbie Wilson. Eleven- year-old boy. Grade five. Accompanied by his mother, Martha Wilson age 42 . Occupation: Secretary, City of Houston-Department of Solid and Liquid Waste Management. Father: Jack Wilson age 45. Occupation: Owner, Wilson Knife Sharpening Company ("JACK \& JAKE-R- SHARPER"). Father is currently at work.

\section{Presenting Problems}

1. School Failure

2. Sleep Problems

3. Groin-slapping Tic

4. Grunting and laughing while slapping.

\section{History of Presenting Problem Situation}

Robbie's mother says his sleep problems and tics started abruptly the day after his $6^{\text {th }}$ birthday. Robbie doesn't fear school and readily attends, but his teachers tell his mother that Robbie daydreams frequently. Though an adequate reader...he seems to resist retaining information, and only makes adequate effort at his math assignments. He likes drawing and prefers to draw "knights of the round table", their armor, their swords and other weapons. Robbie has no friends at school though he gets along $\mathrm{OK}$ with school peers. He gets in no fights and other than his poor grades and day dreaming, his teachers like him. If a teacher asks Robbie to read out loud, he grunts and slaps his groin. The other children laugh when that occurs... as does Robbie. His mother has tried to 


\section{Mental Health \& Human Resilience International Journal}

invite other boys at school to attend sleepovers at the Wilson home, but Robbie rejects the idea.

\section{Family History}

Robbie's mother described no major mental illness in either side of the family but the paternal grandfather had bouts of depression and a drinking problem. The grandfather died the day before Robbie's sixth birthday.

\section{Developmental and Medical History}

Robbie's mother had a normal pregnancy, labor and delivery with Robbie. An only child, Robbie was described as normal in his developmental milestones with the exception of delayed speech. His mother said their pediatrician said Robbie had "Aphrasia". The doctor explained that he had the capacity to talk all along, but not on schedule at two years old. Robbie suddenly commenced completely normal age appropriate speech at age five. He had the usual mumps, measles and chicken pox but no meningitis or severe infections. His hearing has been tested as normal.

\section{Mental Status Exam}

(Dr. Jim Lord's Journal--- Psychiatrists use the term "Mental Status" to describe at one moment in time the functioning of the brain and mind of a person, much, like a cardiologist after examining and listening to the heart, describes the heart size, sounds, murmurs, rubs or other cardiac sounds. The mental status can of course, like heart sounds, change at the time of a subsequent observation. Changes over time can have great clinical importance as can the mental status exam.)

Robbie Wilson is a casually dressed eleven -year- old boy of average height and weight. He has brown hair and eyes. He makes furtive eye contact if directly questioned. He seems distracted by objects in the clinic office or by life in general. (The examiner thinks...Like an absent-minded little professor) Robbie is alert and well oriented to person, place, day of week, month/year-- but not the specific date. His memory is good especially for things he has interested in, but it requires patient probing even prodding to elicit distant memories or details of events. Robbie doesn't seem depressed but is moderately anxious. After his mother is dismissed to the waiting room, he is guarded when asked about his family. His speech is soft but once rapport is established, it has normal flow, rate and quality. It took quite some time to build tentative rapport and barely sufficient trust. Robbie is estimated to be above average in intelligence without any obvious disturbance in thought process or content. At his time he is difficult to engage in active areas where insight or symbolic reasoning could be assessed. He can do math at an appropriate fifth-grade level but has significant anxiety as he utilizes math skills. When the examiner asked Robbie to read from a book Robbie suddenly slapped himself in the groin and made a huffing or grunting noise as he slapped his groin... followed quickly by a nervous laugh and supercilious grin. When asked about "what just happened? -- Robbie shrugged his shoulders and grinned anxiously. His smile was warm and paradoxically engaging despite his obvious embarrassment.

\section{Preliminary Diagnoses}

1. School failure-Probably psychogenic

2. Groin-slapping tic-probably psychogenic, Rule out Tourette's syndrome.

3. Sleep Disorder-unknown etiology.

\section{Treatment Plan}

1. Twice weekly individual psychotherapy sessions.

2. Parent and family conferences PRN.

\section{Dear Journal of Jim Lord}

My report about Robbie Wilson to me sounds so dry, impersonal, stilted, and detached. I guess us doctors have to learn an objective clinical style of writing for reports and courts. To me, it seems wooden, sterile... lifeless. Psychotherapy work with Robbie Wilson is far from lifeless and for me at least, is filled with emotion. For months and months I dreaded each Tuesday and Thursday morning from nine till ten AM. My supervisor Dr. Tom Tolman was supportive but at the same time firm with me. Robbie simply wouldn't or couldn't seem to talk about. His thoughts, fears and feelings. I think Tolman's supervisory process with me was partially therapy. Tolman gradually painstakingly helped me establish good communication with Robbie.

Then after six months of playing checkers, board games, and throwing a ball back and forth for 'rapportbuilding', Tolman recommended to me that I ask Robbie to draw pictures of what he was thinking and feeling. Journal, those pictures were magic! Pure magic for Robbie's psychotherapy treatment process.

\section{The Blurry, Creepy, Cold, Smelly Fuzzies...Help!}

Robbie Wilson had had his usual difficulties falling asleep. He wakes up startled and scared. 


\section{Mental Health \& Human Resilience International Journal}

It's here again! My whole bedroom gets blurry...my eyes fuzzy. That smell. A cold grabby thing creeps up my leg...both legs...it starts at my ankles, then moves up my legs toward my privates...Yike! It's so cold... NO...Don't touch my nuts! Not my privates! NO! Help! Mama! Mama!

Martha Wilson awakes with a start. She runs quickly to Robbie's room at the end of the downstairs hall. She finds Robbie huddled on his bed cringing and facing the wall. When Martha holds Robbie she notes his fixed, detached stare at first, but then, his body tension fades as he slowly accepts comforting.

Martha Wilson thinks,

It happened again! I have to tell doctor Lord about these spells. Does Robbie have epilepsy? Or just Bad dreams?

\section{$* * * * * * *$}

Doctor Lord is nice. I see him every Tuesday and Thursday. I look forward to seeing him. I like him, and not just because he doesn't give shots. He wants me to talk but no words from me come out with him. I know he wants me to say stuff. I don't know where the words he wants are. I like playing checkers and throwing the Nerf ball with him. Doctor Lord has laughter in his eyes. If he actually laughed, I think it would have music in it. Maybe doctors aren't allowed to laugh. Maybe they get in trouble for laughing like some kids at school do. I hope he can help me sleep better and stop hitting myself in the nuts. I just can't stop doing that. It just happens sometimes. When the other kids laugh at me my face gets real red. Then, my ears burn. I laugh at myself. Kids say crying is for babies. I don't want to cry, ever.

Jim Lord says,

"Robbie, at our talks I would like you to draw pictures about what you think and feel...like a comic book where we can put words in the bubbles above the superheroes' heads. Is that OK with you?"

Robbie,

"Sure...what do you want me to draw?"

Lord,

"Draw what comes to your mind. Stuff you picture in your mind."

Robbie sat silent, pencil poised...

Lord says,

"Your mom told me about your waking up scared sometimes. You yell for her to help."

SILENCE-Jim Lord thinks, Tolman has helped me to be comfortable with silence. Tolman says the mind sometimes does hard work during silences in psychotherapy. Like a refueling pit -stop in a long road race. Sometimes in fear, the mind hides somewhere during a silence, like hiding in a game of hide-and-go-seek. Kids imagine, that you can't be seen, hurt or embarrassed in a safe hiding place...Tolman says the psychotherapist can benefit by exploring his or her feelings during the silence or about the silence. Jim finally felt comfortable in and OK with silence in his therapy with Robbie.

Robbie reached out toward his new drawing pad. He drew an oblong egg-shaped object with spikes protruding outward from most of the surfaces. He drew with a remarkably accurate three dimensional quality. Lord at Tolman's suggestion at recent supervision sessions, stayed silent.

(Tolman felt that Robbie should not be interrogated, but would gradually and hopefully begin to put his own words onto the pictures. Tolman said connecting words with feelings, bodily sensations and memories had in and of itself, an inherent therapeutic benefit. But, the therapist best not impose his words on the patient. Even if they accurately fit the feelings, inhibitions, fears or conflicts. The challenge for the child therapist, says Tolman, is how to entwine rapport-building with the stirring of curiosity. Kids are naturally curious, but they learn too soon that many adults are uncomfortable with children's curiosity. Especially curiosity about sex, silliness, body sounds, harmful aggression, and especially, death.)

Finally, Robbie drew stick figure arms and legs on the oval drawn previously. It was perched like a head on top of a short stick neck.

Robbie said,

"I don't like the fuzzy thing in my dream. It scares me." Lord---

"Robbie, are you scared that if you go to sleep you will dream about the scary fuzzy thing?"

Robbie,

"I don't always dream when I sleep...only sometimes. “ Lord,

"Do you know what the fuzzy thing is? You drew arms or legs on it."

Robbie,

"I can't tell if it is an animal, a person, or what?"

Lord recalled that during his evaluation sessions with Robbie, he had asked the standard child psychiatry animal question'---"If your family were animals what animals would they be? "Robbie said his mother would be a big fat lady cow. His father and uncle were two male tigers. When asked about his grandfather, Robbie paused, touched his 


\section{Mental Health \& Human Resilience International Journal}

inner thigh but didn't slap his groin, then said, "An old lion, but he's dead."Robbie himself would be a tiger cub.

The time for their session was up. Tolman had helped Jim to be mindful not to open up new issues at the very end of a therapy session. Tolman said it was like lancing a boil open without time to sew up the wound and bandage properly. So Jim Lord said,

"Robbie, next time let's talk more about that fuzzy scary thing. See you next time."

$* * * * * * *$

At their next session, Robbie seemed distracted. He grabbed the Nerf ball and threw it forcefully at Lord. Robbie laughed and said,

"Nice catch Dr. Lord, you must have been a good baseball player. I wish I was a better baseball player. The boys at school always pick me near last, and for the outfield where nobody hits the ball much. Once, in the outfield, my mind was picturing Dad and Uncle Jake at their shop. Right then a ball was hit right at me but it bounced through my legs and all the way to the outfield fence. Everyone was mad at me for letting a home run get past me".

Jim Lord wanted to get back to discussion of the fuzzy scary thing but, recalled Tolman's admonitions about not imposing his curiosity. Lord chose silence and a tossing of the ball back to Robbie who caught it deftly.

Lord said,

"Nice catch Robbie."

More silence... Robbie began drawing and humming for about ten or fifteen minutes. The tune he sounded like the old song, "When Johnnie comes marching home." Then, Robbie suggested they play checkers. They each won one game before the time was up.

Robbie said,

"Doctor Lord, I want to take my drawing with me and work on it more before we put it in my folder. See you next time Dr. Smiley."

Robbie laughed. Jim Lord smiled and chuckled.

\section{Teachers}

It had been a tough day at school again for Robbie Wilson. Mrs. Klein had asked him to read from their social studies book. Robbie stood up and tried to be brave. Suddenly, he hit himself in the nuts. Damn it! He just couldn't stop that. It was like a magic Halloween ghost put a spell on his arm and hand. Like usual, the kids laughed, and his face got really red. Robbie tried to laugh with them. Mrs. Klein hushed the other kids and asked Larry Jones to read. Robbie imagined he was like Peter Pan in the movie. He could fly away for awhile. The only place he could fly now was into his thoughts. Thoughts are safe places sometimes. If he were alone, he would hum his special song called, "When Robbie comes marching home." When he was alive, Grampa Wilson used to hum and sing that song to himself. "When Johnnie comes marching home, hurrah, hurrah." Mom told Robbie once that Grampa had been shot during the war. She said once that was why Grampa drank too much beer sometimes. So he could forget being shot. Beer also helped Grampa fall asleep.

Robbie thought,

"I like Mrs. Klein. Sometimes I like a school teacher but not many of them. So many teachers just tell you stuff in a bossy way. Good teachers are good smilers. Those good teachers really listen. Their eyes say I like you...I want you to learn. They like to hear your questions, even when they don't know the answer. They smile with you and say things like-

'Robbie, let's look that up in a book. Next time in your library period look it up for us. I will too.' Good teachers remember to discuss the answer at the next class. That makes a book fun for awhile. Like a book reading detective.

I like drawing pictures for doctor Lord. He keeps my drawings in a special folder with my name on it. I like that I have a special folder. I wish Dr. Lord would laugh sometimes. But, he does seem to like me to share my drawings and we talk about them. I liked it when Dad and Uncle Jake used to like my drawings of knives, swords, axes and bayonets. When I drew other things like trees, dogs and people they didn't pay good attention to those pictures. I wish Dr. Lord could meet my Dad and Uncle Jake. I think he would like them like I do. Sometime, I think I will draw a picture of Dad, Uncle Jake and me for doctor Lord.

Jim Lord had begun to look forward to his supervisory sessions with Tom Tolman. This was especially true now that Robbie Wilson's "I think and I feel drawings" had opened up whole new word - worlds in the therapy. 


\section{Mental Health \& Human Resilience International Journal}

Today at supervision, Lord and Tolman studied Robbie's new drawing of his uncle Jake and his father.

Tolman observed,

"Jim, notice in Robbie's drawing he is peering through a window into his father's knife sharpening shop. The stick figures for the two adults are drawn with smiling faces but it looks like they are dueling with two swords, a cutlass and a broad sword."

Jim said,

"Robbie told me his father and uncle were good sword fighters and he didn't watch long because he was sneaking out to watch the men in the evening when he was supposed to be in his room doing school work. Robbie said he secretly watched his father and uncle through that same window... even when he was a little kid."

Tolman said,

"It looks like the swords are aimed or swung at Jake and Jack's genitals! Did Robbie say if they got hurt?

Jim Lord answered,

"Robbie said, he heard them joking and laughing about cutting each other in the nuts. Robbie said that he was scared at first. But his dad and Jake laughed and giggled so he didn't stay scared. I asked Robbie if his dad and Jake had done the same sword play when Robbie was little. He couldn't remember saying that he didn't sneak out there much back then because he got real scared of the dark. I didn't explore the scene any further because Robbie wanted to draw me lots of pictures of swords and fighting knives."

Tolman talked at length about how children's drawings are at times like dreams or day dreams. They solve or try to solve and resolve conflicts, negotiate developmental hurdles, answer questions on their mind, overcome fears and solve sexual mysteries. Finally, Tolman said,

"Jim, it's time to invite Robbie's father and his uncle Jake to a session."

Lord agreed, but felt very nervous about such a session. Lord asked Tolman if Robbie should be at the session with his father and uncle. Tolman felt that Robbie should have the choice. At Robbie's age and his good rapport with Lord, he could handle it.

At Robbie's next session he was fidgety. He tossed the Nerf ball at Jim Lord and they played checkers. After their session, Lord asked Mrs. Wilson to invite her husband and Robbie's Uncle Jake to Robbie's next session. Robbie had not objected. In fact, he had seemed to relish the prospect. Martha Wilson smiled and seemed pleased.

\section{Men in the Family: Jack and Jake Wilson}

Jim Lord tried to prepare himself for the meeting with Robbie Wilson's father and uncle. Lord was tense but eager to meet them.

Jack and Jake Wilson looked remarkably alike. Jack was two years older than Jake and a couple of Inches taller. They presented like two mischievous boys with ready but nervous smiles and they had a Billy Budd innocence about them. They tousled Robbie's hair as the four of them walked down the hall to Lord's office. Robbie took his usual chair near his drawing table and Jack and Jake sat next to each other on the couch facing Lord. Lord quickly intuitively liked Jack and Jake. Robbie seemed comfortable, even pleased in their presence. Robbie had quickly agreed to be present at this session with his dad and uncle. Lord resolved to suspend a final opinion about the brothers Wilson saying,

"Thank you both for coming. Tell me about yourselves and your relationships with Robbie."

Jake Wilson spoke first saying,

"When Martha said you wanted to meet with us I was glad to come. Doctor, I guess you know that Jack and I work together and I room at Jack and Martha's house. Our dad Johnnie built the house and our shop. Dad taught us the business which Jack and I have run now for many years. Dad retired early with a heart condition. I'd say we are a close family that works hard".

Lord asked,

"Jake, does your wife live in the house with you?"

Jake gazed off and thought a minute before saying,

"I have never married. My high school sweetheart and I were engaged but when she died in a car wreck three months before our wedding, I guess I never got over it."

Jake had grown misty-eyed and Jack patted him on the shoulder supportively, saying,

"Doctor, how can we help you to help Robbie with his school problem and that groin slapping thing?

Robbie grinned, blushed and grabbed his crotch gently without an abrupt slap. Lord thought...maybe Robbie

Peter A Olsson. A Boy Who Loved Knives: Resilience Supported through Successful Psychotherapy. Ment Health Hum Resilience Int J 2018, 2(2): 000123. 


\section{Mental Health \& Human Resilience International Journal}

shouldn't be here for this? But, I sense I can go for it directly...here goes.

"Jack and Jake, Robbie has kind of been a young detective with you guys. Even when he was little, he would want to be near you. So he snuck outside to a window at your business building and watched you two through the window. Sometimes you guys apparently were playacting with swords like you were cutting at each others' nuts. That both scared Robbie and fascinated him. As he has gotten older he knows that you would never hurt each other. But, back when he was little, the scary dark and his young mind may have taken those things wrong."

Jack and Jake looked startled and alarmed. Jack Wilson looked genuinely concerned and said sheepishly but intensely,

"Doc we did sometimes have a few beers on Friday nights and would kid around with fake sword or knife play. Shoot Doc, we had no idea Robbie was watching or might be hurt or scared by it."

Robbie grimaced, stared, paying close attention.

Lord said,

"It probably did scare Robbie when he was little kid. But he and I will work hard together to help him get his mind caught-up and strong. The fact that you men came today and clearly want to help Robbie is very important and helpful."

The rest of the hour provided further information about family activities and further information about family history. Johnnie Wilson, Robbie's grandfather, was discussed. Jack and Jake cleared idealized their father and were clearly grateful to him as the provider of their occupation and livelihood. They were unclear about Johnnie's combat wounds in WWII, the details about his heart condition, or when he fully retired. They both acknowledged that Johnnie drank too much but said he was always available to consult if they had a business or technical sharpening problem. Jack said that Johnnie was close to Robbie and would frequently baby sit with Robbie on Friday nights so Jack and Martha could go out to dinner and a movie. Robbie always looked forward to grandpa's ice cream treat.

Lord noticed that during the last twenty minutes of the session Robbie seemed less attentive, pensive and almost drowsy at times.
Robbie's mother called to cancel his next session with Jim Lord. Martha Wilson said that Robbie had stomach flu and had also missed school. Martha Wilson said that Robbie had worse sleep problems and had one of his nighttime scary spells. At the next session Robbie appeared subdued even sullen. They sat in silence for awhile until Robbie said,

\section{"I don't want to come here anymore."}

Lord said,

"Robbie, did something come up after our meeting with your dad and Uncle Jake?"

Robbie looked down and said,

"Nope. We just went out for a burger and fries."

Lord said,

"Robbie, your mom told me that you had a stomach ache, your sleep problem is worse, and you had another scary dream thing."

Robbie looked sad as he said,

"Yeah and I knew if I went to school I'd probably hit my nuts even more."

Robbie tossed the Nerf ball up and down for awhile. When Lord invited him to draw a picture of his feelings Robbie drew a picture of his favorite U.S. Marine K Bar knife with some blood dripping off it. Then, he scribbled over his drawing and said,

"I got to go pee and then have my mom take me home so I can take my stomach medicine."

Lord thought,

Tolman says interruptions to pee during child therapy indicated increased inner tension,

Sometimes a symbolic equivalent of weeping or repressed rage.

Robbie quickly went over to the door of Lord's office to leave. Jim said that he would see Robbie next time. But Robbie shook his head no.

The next day Martha Wilson called Jim Lord to report that Robbie reluctantly went to school but, only when his dad drove him. The sleep problems and nightmares continued. Lord emphasized how important it was for Martha or Jack Wilson to bring Robbie to his next session. 


\section{Mental Health \& Human Resilience International Journal}

\section{To Stab or Not to Stab}

Robbie Wilson stared at the Buck Ranger Skinner knife his dad had given him last Christmas. It was his second favorite to his U.S. Marine K Bar that his grandpa Johnnie used when he was a marine. Grandpa Johnnie left him the $\mathrm{K}$ Bar in his will when he died.

Robbie loved the Ranger Skinner knife's short sharp sturdy steel three and one eighth inch blade. The smooth Dymondwood handle fit just right in his hand. The Ranger Skinner looked cool in its dark brown sheath. When he was hiking in Bear Creek Park sometimes with his dad, Robbie felt strong and safe. As he stared at the blade Robbie thought,

I thought I liked doctor Lord. But now I wish I could stick him with this knife. Then he would hurt like I did when he got me to tattle on dad and Uncle Jake. I am a rat fink for telling on them. I am pissed at Dr. Lord. Mom and dad say I got to see Dr. Lord today. I'll only go because Dad is taking me. My stomach hurts bad now.

Before Robbie and his dad left for the appointment with Dr. Lord, Robbie slid the Ranger

Skinner knife and its Sheath into the side button-down pocket of his Camo pants.

Robbie Thought,

I don't want to talk to Dr. Lord today or draw stupid pictures. Dad says I got to See him. Crap, my stomach hurts. I wish Dr. Lord would lose sleep and hit his Nuts sometimes.

Robbie smiled a little grimly when his dad called him to go to his appointment.

Jim Lord was glad to see Robbie and his dad in the waiting room. As their session began Robbie seemed distracted, restless, and distant. When asked to draw pictures about his feelings, Robbie refused. He fiddled with the buttoned pocket of his Camo pants. Lord said, “Robbie you haven't worn those pants before. They have cool pockets to keep stuff. What do you have in the pocket today?"

Robbie frowned, blushed and rubbed his stomach. With his other hand, Robbie unbuttoned the pocket flap and pulled out the Ranger Skinner knife in its sheath. Robbie said,

"I thought about sticking you with this knife when you made me rat on my dad and Uncle Jake. I could sure draw a bloody picture of my thoughts about you."

Lord said,

"It's good you brought up your angry thoughts about me. But, it was helpful that your dad, Jake, you and me all could talk about what got you scared as a younger kid. Your dad and Uncle Jake don't see you as rat finking on them. As you grow older now you don't have to lose sleep or get scared about stuff. You can picture fears in your mind and find words for them. Then you can find out what to do about them without anyone getting hurt. Tell me about your knife."

Robbie was quiet for awhile. He gripped the knife tightly. He looked doubtful at first but gradually grew more relaxed as he talked about the Ranger Skinner Knife. With some enthusiasm he talked about what the cowboys used it for on the cattle ranches. Robbie also drew a picture of the throwing knife that his dad taught him to throw at dead tree stumps at Bear Creek Park. After letting Jim Lord admire it, Robbie put the Ranger Skinner knife in its sheath back in his pocket. Before Robbie left the session he handed the picture of the throwing knife to Jim to put in his special clinic folder.

$* * * * * * *$

At their supervision session Tom Tolman listened carefully and asked questions about Robbie Wilson's contemplated attack on Lord and Jim's reaction.

Tolman asked,

"What was Robbie telling you?"

Jim responded,

"I have no idea beside how important his dad and uncle are to him. Also how protective he is towards them. I thought therapy had been going well but his thinking about knifing me got scary. Does he have thoughts of castrating me?

Tolman said,

"You may not agree but I think Robbie's therapy has made real progress. Your tuning into your intuitions shows you are making good progress as a therapist. Even if you don't feel like it Jim, I can see it. Robbie's response to your clarifying intervention tells me that the therapy is on track. 


\section{Mental Health \& Human Resilience International Journal}

About your question about castration, I assume the picture he made for you of the throwing knife had no blood on it. There may be someone else in Robbie's unconscious mind that knifing is intended for, but it isn't you. By the way, I think you should see Robbie's dad, or dad and mom after one of Robbie's sessions each week for awhile. Some family secrets might be emerging and hopefully the Wilson family is able do the work to resolve them."

Jim checked the throwing knife picture and the red crayon had not been used on the knife picture. Jim Lord felt good about the session with Tolman. He knew that Tolman would not make idle complements about his work unless they were authentic.

Martha Wilson called the next day leaving a message for Jim Lord indicating that Robbie had a bad dream and had missed school again. Robbie had a stomachache.

Jim thought,

"Like Tolman often says, "One step forward two steps back."

$* * * * * * *$

At Robbie's next session with Jim Lord he was more relaxed, played some checkers with Jim but spoke about how much he hated school lately. After the session Jim Lord met with Robbie's mother.

Martha Wilson was dressed neatly in a conservative looking gray pants suit. She had her gray hair in a pony tail. She had an attractive figure but her tense clenched jaw and hands matched her furrowed brow. She described Robbie's fearful awakening from his nightmare. Jim Lord asked,

"Ms. Wilson, tell me more about Robbie and his sleep patterns."

Martha Wilson said,

“Doctor Lord, Robbie's nightmares and sleep have always been a problem. But, they are worse recently. I have noticed they are more likely to occur on Friday nights or rarely on Sunday night. Jack and I like to go out for dinner and a movie on Friday nights. The teenage girls in the neighborhood used to baby sit when Robbie was little but Robbie never wanted a boy baby sitter. Jake sometimes stays with Robbie when we are out which Robbie likes. His grandpa Johnnie was Robbie's favorite baby sitter because he always had ice cream for them to enjoy."
Lord asked Martha,

"Do you remember how Robbie reacted when your fatherin-law died? Robbie was five when Johnnie died."

Martha Wilson told Lord that Robbie's grandpa Johnnie Wilson had been baby sitting with Robbie the night Johnnie died. Jack and Martha Wilson returned home after a movie to find Johnnie lying dead on his bed. Robbie was sitting frozen-like on a chair near his dead grandfather. They all were shocked.

Lord asked Martha Wilson, "Had Johnnie been drinking that evening? "

Martha Wilson looked tense but responded quickly, "Johnnie drank too much beer and he had been drinking more the months before he died. His doctor had cautioned him about his beer belly and weight gain. We thought Johnnie only drank more beer after Robbie was asleep or after we got home after the movie. Many other nights I heard Johnnie pop beers late at night in the kitchen."

Martha went on tearfully,

"The night we found Johnnie dead, there was noticeable beer smell around his bed where he had been reading to Robbie about Marine Corp history. We sometimes found both Robbie and Johnnie asleep when we got home from a late movie but I don't remember beer smell like that before that night."

At their next supervisory meeting Tom Tolman agreed with Jim Lord that he and Robbie needed to talk about the night Johnnie died.

Jim Lord awaited Robbie's next session with anxiety. He felt tension in his neck and like Robbie, Jim had a queasy stomach before Robbie entered his office. Robbie seemed more relaxed that Lord as the session started.

Jim said,

"We need to talk or draw pictures of the night your grandpa Johnnie died. Your mom talked to me about that night when they found Johnnie dead and you sitting nearby his bed. He had been reading to you about marines."

Robbie grabbed his stomach and slapped his groin with a low groaning sound. Robbie started to move toward the door.

Jim said,

"Don't leave. Tell me or draw me a picture of what happened." 


\section{Mental Health \& Human Resilience International Journal}

Robbie grew tight-lipped and began to draw rapidly on paper. He drew a crude sketch of Johnnie's bed with a book beside Johnnie on the bed and Robbie standing near the bed and punching Johnnie in the chest. Robbie then sat dazed staring at Jim Lord.

Jim said,

"Robbie, had Johnnie touched you?"

Robbie drew a quick sketch of the fuzzy round thing he had drawn for Lord before and said,

"I liked the stories about the marines but grandpa was crying and talking funny about his buddies dying. He had that stinky smell of beer and he was hugging me and feeling my legs and moving up toward my nuts. I punched him hard in his chest and got out of his bed. Grandpa got a scared look on his face and couldn't breathe. I killed grandpa! I know I did! “

Robbie slumped in his chair and scratched across his pictures with a pencil.

Jim said,

"Robbie. You did not kill Johnnie. The doctors knew he had a heart problem and he died from a heart attack. Not your punch."

Robbie started to cry saying in a bitter tone, "How do you know Dr. Lord?"

Jim Lord said,

"Because I am a doctor that knows about heart attacks as well as problems with fears and feelings. I can find Johnnie's medical records for us to read and even have you and I talk to his doctor to prove that he died from a heart attack and not your punch."

Robbie said,

"You would do that with me?"

Jim said,

"Yes I would and I also want you to know that Johnnie's touching of you was wrong. That was his problem, not yours! It was good for you to punch him to make him stop. I think we will find out together that Johnnie's touching your legs and nuts makes you have sleep problems and you're hitting yourself in the nuts."

There was a long silence during which Robbie slowly stopped crying and Jim Lord was taking deep breaths. Lords neck tension and queasy stomach disappeared. Robbie put his drawings in his folder and handed it to Jim.
Jim Lord told Robbie he would see him next time. Robbie had no comment and joined his father in the waiting room.

$* * * * * * *$

Several follow-up sessions with Martha, Jack and Jake Wilson was poignancy defined. At first all three adults were stunned, disbelieving, and then tearful. They then with support began to share about the Johnnie Wilson they had loved, put on a pedestal, and by whom they had been intimidated. Jack and Martha agreed to obtain Johnnie's medical and autopsy record and ask Johnnie's doctor if he would explain Johnnie's death to Robbie in person if Jim Lord felt it was necessary.

At a final session, Jake Wilson surprised Martha and Jack by reporting that he had confronted Johnnie about drinking beer around Robbie. Johnnie denied drinking around Robbie when they were alone together. But then, Johnnie had improved in his drinking behavior for awhile. Jake at that session did describe a fuzzy scruffy-looking beard that Johnnie had sported the last few months of his life. Johnnie told Jake that during bitter battles with the Japanese he and his marine buddies had all grown beards. Neither Jake, Jack, nor Martha had any inkling that Johnnie might ever have fondled Robbie.

Jim Lord and Robbie's talk with Johnnie's doctor named Cliff Peterson was helpful. Robbie asked Peterson directly if he had caused his grandpa's death. Peterson impressed Lord by treating Robbie's question seriously, clearly and kindly. Robbie appeared satisfied.

Robbie's subsequent sessions with Jim Lord were lively with fun Nerf ball throwing. Robbie drew many pictures for his folder. In several pictures he drew the "Smelly, fuzzy 'bad guy'. The bad guy got chased away by Robbie holding his Ranger Skinner knife.

Subsequent to such active sessions Robbie ceased having nightmares. He no longer feared embarrassing groin-slapping episodes, because they had completely ceased. Lord, Robbie's teacher and especially Robbie were pleased.

Jim spent a final supervisory session with Tom Tolman talking about how he was going to miss Robbie. He thanked Tolman for his help and that he had decided to go into child psychiatry ...specializing in child psychotherapy. 
After Jim had left Tolman's office, Tom felt good about being a teacher of psychotherapy.

In the final months of Robbie Wilson's psychotherapy, he talked about enjoying school. He was looking forward to the baseball season because he and his dad had been practicing with him and his friends. At his final session with Jim Lord Robbie gave Lord an early Christmas gift... A Swiss Army knife. Robbie said that he, Jake, or his dad would be glad to sharpen it anytime it needed it.

\section{Lessons Learned from Robbie Wilson}

Work with Robbie in psychotherapy taught me that family resilience sometimes provides a valuable synchrony in support of a child's cure in psychotherapy. Family history of secrets, abuse and conflicts comes to life therapeutically when family members have the courage to confront issues and deal with them in treatment.

In addition, the use of a child's drawings or other art modalities can be very helpful during the therapy process.

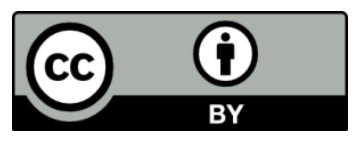

